\title{
Pengaruh karakteristik perusahaan terhadap kinerja sosial berdasar ISO 26000 pada perusahaan yang termasuk dalam indeks LQ- 45
}

\author{
Sri Wahjuni Latifah, Adi Prasetyo, R. Farid Rahadian \\ Universitas Muhammadiyah Malang, Jawa Timur \\ Jl. Raya Tlogomas 246 Malang \\ Email:yuni_latifah@yahoo.co.id
}

\begin{abstract}
This research represents empirical study to disclosure practice of corporate social performance (CSP) based on ISO 26000 at company in index LQ45. Social performance disclosure based on ISO 26000 of company is such as the details of organizational governance, human rights, labor practices, the environment, fair operating practices, consumer issues, community involvement and development.

The purpose of this research is to looking for evidence about characteristic company influences to corporate social performance disclosure based on ISO 26000 at company in index LQ45. Age company measured from company was borned until annual report have been made, profitability measured with ROA and company type to be classified by high profile and low profile.

Sample companies determined by purposive sampling method. Documentation method technique is used to collect the data. Data analysis used item check list and for to know the influence of company charachteristics used linear multiple regression. Data processing in this research used application SPSS v.17. Result of $F$ test declare simultaneously find the effect between company charachteristics to CSP disclosure. The author find result of $t$ test declare that profitability and type company lack the effect between company charachteristics to CSP disclosure.
\end{abstract}

Keywords : CSP, ISO 26000, company's characteristic

\section{Pendahuluan}

Isu lingkungan dan sosial berkaitan dengan perkembangan bisnis di era global, menjadi tema yang banyak diperbincangkan dikalangan para akuntan. Hal ini seiring dengan perkembangan sector industry serta era globalisasi yang semakin pesat, maka persaingan yang berkaitan dengan competitive advantage semakin tinggi baik di dalam maupun luar negeri. Salah satu cara untuk dapat memenangkan persaingan tersebut adalah dengan menghasilkan produk yang berkualitas tinggi melebihi harapan pelanggan. Namun peningkatan kualitas produk yang seringkali kurang seimbang dengan peningkatan kualitas lingkungan dan sosialnya.

Faktor itulah yang menjadi tantangan bagi perusahaan agar lebih memfokuskan perhatiannya pada upaya untuk menciptakan kelestarian lingkungan dan sosialnya di samping menghasilkan produk yang berkualitas, sebab badan usaha tidak dapat dipisahkan dari lingkungan serta sosial, di mana badan usaha tersebut berdiri. Bahkan masalah lingkungan ikut mempengaruhi persaingan bisnis baik nasional maupun internasional dan menjadi salah satu faktor penentu produk tersebut layak atau tidak di jual ke seluruh dunia. Dan di satu kesempatan yang

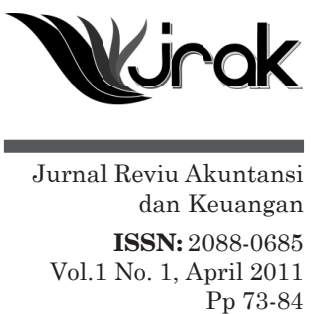




\section{Pengaruh karakteristik perusahaan}

lain, Hackston \& Milne (1999) mengatakan bahwa perusahaan yang berorientasi pada konsumen diperkirakan akan memberikan informasi mengenai pertanggungjawaban sosial karena hal ini akan meningkatkan image perusahaan dan meningkatkan penjualan.

Kinerja yang dilakukan perusahaan tidak akan terlepas dari dampak globalisasi, kemajuan teknologi informasi dan keterbukaan pasar. Oleh karena itu, perusahaan harus serius dan terbuka memperhatikan kinerjanya terutama kinerja sosial yang dalam dunia bisnis sering disebut dengan tanggung jawab sosial perusahaan (Corporate Social Responsibility/CSR). Perusahaan yang melaksanakan CSR dikatakan telah memenuhi triple bottom line: sosial, lingkungan, dan ekonomi (Darwin, 2004).

Namun pada praktik CSR di Indonesia, baru bisa dimulai pada awal tahun 2000, walaupun kegiatan dengan esensi dasar yang sama telah dimulai sejak tahun 1970-an, dengan tingkat yang bervariasi, mulai dari yang paling sederhana seperti donasi sampai kepada yang komprehensif seperti terintegrasi ke dalam strategi perusahaan dalam mengoperasikan usahanya. Jalal (2008) menyatakan bahwa dekade 1970-an ditandai dengan munculnya konsep enlightened self interest, yang berupaya menyediakan rekonsiliasi antara tujuan sosial dan ekonomi perusahaan. Penulis tersebut dengan tegas menyatakan bahwa CSR akan terus menjadi konsep asing apabila tidak berhasil menunjukkan dirinya konsisten dengan kepentingan pemilik modal.

Pelaksanaan program CSR memang mulai berkembang pesat pada periode 1970-1980 seperti yang sudah dijelaskan, namun perusahaan-perusahaan yang telah melaksanakan program CSR pada periode tersebut mulai mencari model CSR yang dapat mengukur dampak pelaksanaan CSR oleh perusahaan terhadap masyarakat serta sejauh mana pelaksanaan CSR sebagai suatu investasi sosial memberikan kontribusi bagi peningkatan kinerja keuangan perusahaan seperti yang sudah dijelaskan oleh Solihin (2008). Kebutuhan ini telah mendorong lahirnya konsep Corporate Social Performance (CSP) atau disebut juga dengan kinerja sosial sebagai penyempurnaan atas konsep CSR sebelumnya (Solihin, 2008).

Kinerja sosial merupakan hal yang cukup penting bagi citra (reputation) perusahaan, terutama untuk jangka panjang perusahaan yang dapat memberi kontribusi cukup berarti dalam pengembangan berkelanjutan bagi perusahaan. (Yunan, 2005 dalam Maulana, 2008). Dengan demikian kinerja sosial dapat menjadi salah satu ukuran bagi citra atau reputasi perusahaan. Citra atau reputasi perusahaan sendiri merupakan salah satu asset yang sangat berharga.

Salah satu tema sentral yang dibawa oleh konsep kinerja sosial adalah bagaimana perusahaan dapat mengukur tindakan serta hasil dari tindakan sosial yang dilakukan perusahaan, seperti halnya perusahaan dapat mengukur aktivitas operasional lainnya. Hal ini menjadi sangat penting bagi perusahaan, karena pelaksanaan program CSR yang dilakukan perusahaan dibiayai oleh sumber dana perusahaan yang sifatnya terbatas. Padahal dana yang dikeluarkan oleh perusahaan untuk kegiatan CSR jumlahnya tidaklah kecil.

Pengungkapan sukarela baik kinerja sosial maupun kinerja lainnya, dipengaruhi oleh beberapa faktor, antara lain karakteristik perusahaan yang bersangkutan. Karakteristik tersebut meliputi ukuran perusahaan, umur perusahaan, kepemilikan manajemen, profil perusahaan, rasio likuiditas, rasio leverage, profitabilitas, ukuran dewan komisaris, dan tipe perusahaan. Anggraini (2006) dalam penelitiannya menyatakan bahwa persentase kepemilikan manajemen dan tipe industri berpengaruh signifikan terhadap kebijakan perusahaan dalam mengungkapkan informasi sosial. Namun beberapa penelitian yang telah dilakukan peneliti lain memberikan hasil yang bervariasi, misalnya pada penelitian Susanto (1992) terhadap 98 laporan tahunan perusahaan yang terdaftar di BEJ tahun 1990 menjelaskan hasil bahwa size, basis perusahaan dan kepemilikan saham oleh publik berpengaruh secara signifikan terhadap luas pengungkapan. Sedangkan penelitian yang dilakukan oleh Marwata (2001) menunjukkan bahwa hanya variabel size 
yang berpengaruh terhadap luas pengungkapan sukarela, sedangkan variabel yang lain tidak mempunyai pengaruh yang signifikan. Utomo (2000), Henny dan Murtanto (2001) melakuan penelitian pengungkapan tanggung jawab sosial perusahaan high profile dan low profile dalam laporan tahunan perusahaan yang terdaftar di Bursa Efek Jakarta. Dalam penelitiannya mereka menemukan bahwa tipe industri high profile mengungkapkan lebih banyak dari tipe industri low profile. Sedangkan penelitian yang dilakukan Davey (1982) dan Ng (1985) dalam Hackston dan Milne (1996) tidak menemukan hubungan antara kedua variabel tersebut. Oleh karena itu, segala aktivitas perusahaan harus diungkap pertanggungjawaban social dan lingkungan yang mereka ciptakan.

Adapun salah satu wujud kepedulian perusahaan atas kinerja sosial, kini dapat di jawab dengan sertifikasi ISO 26000 yang merupakan standar baru internasional yang dapat dijadikan pedoman perusahaan-perusahaan pelaku kegiatan usaha yang wajib melakukan tanggung jawab sosial dan lingkungan tentunya. ISO 26000 menjadi kunci penting untuk mendorong CSR yang substansial dan komprehensif.

Kehadiran ISO 26000 sebagai pedoman untuk diterapkan dan diyakini akan makin memacu perusahaan-perusahaan di dunia, termasuk Indonesia, untuk berCSR secara benar. Dengan adanya panduan, maka perusahaan akan makin mudah dalam menerapkan konsep CSR. Harus diakui bahwa selama ini tidak ada panduan tentang pelaksanaan CSR. Akibatnya banyak perusahaan yang menginterpretasikan konsep sesuai dengan pemikiran masing-masing. Akibatnya banyak yang melakukan kegiatan CSR hanya di permukaan saja tanpa menyentuh substansi, seperti misalnya melakukan hal yang bersifat charity semata.

Berdasarkan uraian tersebut, maka penelitian ini dilakukan dengan tujuan membuktikan dan menguji bagaimana pengaruh dari karakteristik perusahaan yang diukur dengan umur perusahaan, return on assets dan tipe perusahaan dengan kinerja sosial berdasar ISO 26000 pada perusahaan-perusahaan yang termasuk dalam indeks LQ 45 di Indonesia.

\section{Pengembangan Hipotesis}

Teori stakeholder memberikan kerangka dasar pola pikir penggeseran pengelolaan ke stakeholders orientation tersebut. Dengan esensi teori legitimasi menjelaskan bahwa untuk menjamin dan menjaga keberpihakan (legitimasi) stakeholders baik internal maupun eksternal, perusahaan perlu menjamin congruencesi antara keberadaan dan tujuan perusahaan terhadap pengharapan stakeholders (Deegan, 2000).

Hal itu, sejalan dengan kaidah teori stakeholder yang menjelaskan bahwa keberadaan perusahaan tak dapat dilepas dari stakeholders. Stakeholders adalah semua pihak yang secara langsung maupun tidak langsung mempengaruhi dan dipengaruhi perusahaan (Luk. et. al, 2005). Stakeholders is a group or an individual who can affect, or be affected by, the success or failure of an organization (Luk, Yau, Tse, Alan, Sin, Leo dan Raymond, 2005).

Stakeholders adalah para pihak baik internal (karyawan), maupun para pihak eksternal (pemerintah, LSM, masyarakat, lingkungan, organisasi pemuda, organisasi sosial, investor, kreditor, kepelanggan, calon pelanggan, supplier dan sejenisnya) (Kasali, 2005)

Windsor (2010) mengatakan bahwa ISO 26000 sedang dikembangkan sekarang. ISO tidak meliputi syarat-syarat dan tidak menjadi sebuah sertifikasi standar untuk saat ini. Menariknya, ciri-ciri pada pengungkapan sukarela dengan atau tidak dengan tanda ciri-ciri tersebut, sebagaimana perusahaan mengungkapkan dan mendapatkan tanda yang diijinkan namun jika itu tersedia, mengingat perusahaan melihat seberapa kuat dorongan untuk melakukan pengungkapan itu. 


\section{Pengaruh karakteristik perusahaan}

Seperti dalam penelitian Sembiring (2005) dan Suripto (1999), mereka berhasil menemukan adanya korelasi antara umur perusahaan terhadap pengungkapan tanggung jawab sosial. Sehingga hipotesis 1 penelitian ini adalah: Umur perusahaan (age) berpengaruh positif terhadap pengungkapan kinerja sosial berdasar ISO 26000.

Profitabilitas merupakan faktor yang membuat manajemen menjadi bebas dan fleksibel untuk mengungkapkan pertanggungjawaban sosial kepada pemegang saham (Heinze, 1976 dalam Hackston dan Milne, 1996). Ketika perusahaan memiliki tingkat laba yang tinggi, perusahaan (manajemen) menganggap tidak perlu melaporkan hal-hal yang dapat mengganggu informasi tentang sukses keuangan tersebut. Sebaliknya ketika tingkat profitabilitas rendah perusahaan akan berharap pengguna laporan akan membaca "good news" kinerja perusahaan. Berdasarkan uraian di atas, hipotesis 2 penelitian ini adalah: Tingkat profitabilitas perusahaan berpengaruh negatif terhadap pengungkapan kinerja sosial berdasar ISO 26000.

Para peneliti akuntansi sosial tertarik untuk menguji pengungkapan sosial pada berbagai perusahaan yang memiliki perbedaan karakteristik. Salah satu perbedaan karakteristik yang menjadi perhatian adalah tipe perusahaan, yaitu perusahaan yang high-profile dan perusahaan yang low-profile. Untuk membedakan kedua jenis perusahaan tersebut, definisi yang diusulkan oleh Robert (1992) dalam Hackston and Milne (1996) dapat dipergunakan. Robert mendefinisikan high-profile companies sebagai perusahaan yang memiliki consumer visibility, tingkat risiko politik dan tingkat kompetisi yang tinggi.

Perusahaan yang high-profile diyakini melakukan pengungkapan sosial yang lebih banyak daripada perusahaan yang low-profile. Cowen et al.(1987) dalam Hackston dan Milne (1996) menambahkan bahwa perusahaan yang berorientasi pada konsumen diperkirakan akan memberikan informasi mengenai pertanggungjawaban sosial karena hal ini akan meningkatkan image perusahaan dan mempengaruhi penjualan. Sementara itu, Hackston dan Milne (1996) mengatakan bahwa perusahaan yang memiliki aktivitas ekonomi yang memodifikasi lingkungan, seperti perusahaan ekstraktif, lebih mungkin mengungkapkan informasi mengenai dampak lingkungan dibandingkan perusahaan yang lain. Berdasarkaan uraian di atas maka hipotesis 3 sebagai berikut: Tipe perusahaan berpengaruh positif terhadap pengungkapan kinerja sosial berdasar ISO 26000.

\section{Metode}

Populasi dalam penelitian ini adalah perusahaan-perusahaan yang terdaftar di Bursa Efek Indonesia (BEI). Penentuan sampelnya dilakukan dengan menggunakan metode purposive sampling. Kriteria yang digunakan dalam penentuan sampel adalah perusahaan kategori high profile dan low profile yang termasuk dalam indeks LQ 45. Dalam data yang digunakan dalam penelitian ini terdapat 36 units dan 1 time period. Tiga puluh enam unit menunjukkan jumlah perusahaan yang menjadi sampel dan 1 time periode menunjukkan periode data observasi yaitu tahun 2009. Data yang digunakan dalam penelitian ini adalah data sekunder yang diperoleh dari: IDX (Indonesian Stock Exchanges), jurnal, makalah, penelitian, buku, dan situs internet yang berhubungan dengan tema penelitian ini.

Data diperoleh dari annual report perusahaan yang menjadi sampel dan telah dipublikasi di Bursa Efek Indonesia.Metode pengumpulan data dalam penelitian ini dilakukan dengan metode dokumentasi.

\section{Variabel Penelitian}

Varibel penelitian ini ada dua, yaitu variabeldependen dan independen. Variabel dependen dalam penelitian ini adalah:Kinerja sosial perusahaan berdasar ISO 26000 dibagi dalam tujuh kategori, Kategori-kategori tersebut terbagi dalam 34 item pengungkapan. Item pengungkapan ISO 26000 yang digunakan menjadi 
pengungkapan kinerja sosial dalam penelitian ini. Kategori serta item tersebut didapatkan di www.csrindonesia.com.

Kinerja sosial diukur dengan :

Keterangan:

$$
\frac{\sum X n}{34} \times 100 \%
$$

- $\quad \sum X n$ adalah jumlah pengungkapan perusahaan sampel

- 34 adalah jumlah item pengungkapan dalam ISO 26000

Sedangkan variabel independen penelitian ini terdiri dari faktor-faktor yang mempengaruhi hubungan kebijakan perusahaan dengan kinerja sosial yang meliputi:

a. Umur Perusahaan (age)

Pengukuran umur perusahaan dihitung sejak ber dirinya perusahaan sampai dengan data observasi (annual report) dibuat.

b. Profitabilitas (prof)

Profitabilitas perusahaan diukur dengan Return on Asset (ROA) sebagaimana telah dilakukan dalam penel itian Amran dan Devi (2008), yaitu membandingkan antara laba bersih setelah pajak dengan total aset.

c. Tipe Perusahaan (company type)

Tipe perusahaan diukur dengan menggunakan checklist, yaitu pemberian skor 2 untuk perusahaan yang termasuk dalam perusahaan high-profile, dan skor 1 untuk perusahaan yang termasuk dalam perusahaan low-profile. Kriteria untuk menentukan perusahaan termasuk high-profile dan low-profile digunakan pengelompokan menurut, Muhammad Rizal Hasibuan (2001), Muhammad Muslim Utomo (2000) maupun Henny dan Murtanto (2001) memasukan perminyakan dan pertambangan, kimia, hutan, kertas, otomotif, penerbangan, agrobisnis, tembakau dan rokok, makanan dan minuman, media dan komunikasi, energi (listrik), engineering, kesehatan, transportasi dan pariwisata sebagai perusahaan yang high profile sedangkan bangunan, keuangan dan perbankan, suplier peralatan medis, properti, retailer, tekstil dan produk tekstil, produk personal, produk rumah tangga sebagai perusahaan yang low profile.

\section{Metode Analisis Data}

Selanjutnya penelitian ini menggunakan beberapa tahapan analisis data:

Uji Asumsi Klasik

- Uji Normalitas

Uji normalitas bertujuan menguji apakah dalam model regresi, variabel pengganggu atau residual memiliki distribusi normal (Ghozali, 2007). Uji normalitas ini menggunakan uji statistik Frequencies.

- Uji Multikolinearitas

Ghozali (2007) menyebutkan uji multikol inearitas bertujuan untuk menguji apakah model regresi ditemukan adanya kolerasi antara variabel bebas.

- Heteroskedastisitas

Uji heteroskedastisitas bertujuan menguji apakah dalam model regresi tejadi ketidaksamaan varian dari residual satu pengamatan ke pengamatan yang lain. 


\section{Pengaruh karakteristik perusahaan} 78

\section{Pengujian Hipotesis}

\section{Uji Regresi Berganda}

Metode regresi berganda (multiple regression), dilakukan terhadap model yang diajukan peneliti dengan menggunakan Software SPSS Versi 17 untuk memprediksi hubungan antara 2 variabel independen atau lebih dengan 1 variabel dependen. Dalam hal ini, karakteristik perusahaan sebagai variable independen dan kinerja sosial berdasar ISO 26000 sebagai variable dependen, dapat diukur dengan rumus:

$Y^{\prime}=a+b_{1} X_{1}+b_{2} X_{2}+b_{3} X_{3}$

\section{Keterangan:}

Y' = Indeks pengungkapan nilai kinerja sosial berdasar ISO 26000

a $\quad$ Konstanta; besarnya sama dengan $\mathrm{Y}^{\prime}$ jika $\mathrm{X}_{1}, \mathrm{X}_{2}$ dan $\mathrm{X}_{3}=0$

$\mathrm{b}_{1}, \ldots \mathrm{b}_{3}=$ Koefisien regresi

$\mathrm{X}_{1}=$ Umur Perusahaan

$\mathrm{X}_{2} \quad=$ Rasio Profitabilitas

$\mathrm{X}_{3} \quad=$ Tipe Perusahaan

\section{Uji Statistik Simultan (F test) dan Uji Regresi Parsial (t test)}

Uji statistik simultan atau disebut juga dengan analisis varian (ANOVA) merupakan uji koefisien regresi secara bersama-sama (uji F) untuk menguji signifikansi pengaruh beberapa variabel independent terhadap variabel dependent. Dalam hal ini peran ANOVA adalah untuk menguji signifikansi pengaruh umur perusahaan, tingkat profitabilitas dan tipe perusahaan secara bersama-sama terhadap kinerja sosial berdasar ISO 26000. Pengujian ini menggunakan signifikansi 0,05 atau 5\%. Hipotesis akan diterima ataupun ditolak berdasarkan signifikansi:

Uji koefisien regresi secara parsial atau biasa disebut Uji t, digunakan untuk mengetahui apakah secara parsial umur perusahaan, tingkat profitabilitas dan tipe perusahaan berpengaruh secara signifikan atau tidak terhadap kinerja sosial berdasar ISO 26000. Hal itu diukur menggunakan tingkat signifikansinya.

\section{Hasilpenelitian dan Pembahasan}

Dari hasil perhitungan variabel penelitian dependen mengenai tingkat kinerja sosial dari 36 sampel mengenai penilaian kinerja sosial sesuai dengan itemitem ISO 26000 menggunakan skala dummy, maka diperoleh rekap hasil perhitungan. Hasil tersebut dapat dilihat pada tabel sebagai berikut:

\begin{tabular}{|c|c|c|c|c|c|}
\hline \multicolumn{5}{|c|}{ ISO } & \multirow{2}{*}{$\begin{array}{c}\text { ISO } \\
26000\end{array}$} \\
\hline No & Nama Perusahaan & 26000 & No & Nama Perusahaan & \\
\hline 1 & PT BISI INTERNASIONAL Tbk & 0,529 & 19 & PT ANEKA TAMBANG (Persero) Tbk & 0,559 \\
\hline 2 & PT BERLIAN LAJU TANKER Tbk & 0,529 & 20 & PT ASTRA INTERNASIONAL Tbk & 0,471 \\
\hline 3 & PT BANK MANDIRI (Persero) Tbk & 0,824 & 21 & PT BARITO PASIFIK Tbk & 0,559 \\
\hline 4 & PT HOLCIM INDONESIA TbK & 0,647 & 22 & PT ELNUSA Tbk & 0,588 \\
\hline 5 & PT LIPPO KARAWACI TbK & 0,5 & 23 & PT INTERNASIONAL NIKEL INDONESIA TbK & 0,618 \\
\hline 6 & PT INDOSAT TbK & 0,618 & 24 & PT INDOFOOD SUKSES MAKMUR TbK & 0,618 \\
\hline 7 & PT MITRA INTERNASIONAL RESOURCES TbK & 0,5 & 25 & PT ASTRA AGRO LESTARI Tbk & 0,529 \\
\hline 8 & PT PANIN BANK TbK & 0,529 & 26 & PT INDOCEMENT TUNGGAL PERKASA TbK & 0,588 \\
\hline 9 & PT JASA MARGA (Persero) Tbk & 0,588 & 27 & PT TAMBANG RAYA MEGAH Tbk & 0,588 \\
\hline
\end{tabular}

Tabel 1

Indeks Kinerja Sosial Berdasar ISO 26000 


\begin{tabular}{|c|c|c|c|c|c|}
\hline \multicolumn{5}{|c|}{ ISO } & \multirow{2}{*}{$\begin{array}{c}\text { ISO } \\
26000\end{array}$} \\
\hline No & Nama Perusahaan & 26000 & No & Nama Perusahaan & \\
\hline 10 & PT SAMPOERNA AGRO Tbk & 0,559 & 28 & PT KALBE FARMA Tbk & 0,588 \\
\hline 11 & PT ADARO ENERGY Tbk & 0,706 & 29 & PT MEDCO ENERGY INTERNASIONAL Tbk & 0,647 \\
\hline 12 & PT BANK CENTRAL ASIA Tbk & 0,765 & 30 & PT PERUSAHAAN GAS NEGARA (Persero) Tbk & 0,735 \\
\hline 13 & PT BANK NEGARA INDONESIA (Persero) Tbk & 0,941 & 31 & PT BUKIT ASAM (Persero) Tbk & 0,735 \\
\hline 14 & PT BANK RAKYAT INDONESIA (Persero) Tbk & 0,853 & 32 & PT TELKOMUNIKASI INDONESIA Tbk & 0,912 \\
\hline 15 & PT SEMEN GERSIK (Persero) Tbk & 0,882 & 33 & PT DANAMON INDONESIA TbK & 0,735 \\
\hline 16 & PT TIMAH (Persero) Tbk & 0,912 & 34 & PT INDIKA ENERGY Tbk & 0,5 \\
\hline 17 & PT BAKRIE SUMATERA PLANTATIONS Tbk & 0,794 & 35 & PT PP LONDON SUMATRA Tbk & 0,676 \\
\hline 18 & PT UNITED TRACTORS TbK & 0,882 & 36 & PT UNILEVER INDONESIA TbK & 0,853 \\
\hline
\end{tabular}

Sumber : Data diolah tahun 2011

Berikut adalah hasil perhitungan nilai karakteristik perusahaan dengan cara pengukuran yang sudah disesuaikan:

\begin{tabular}{|c|c|c|c|c|}
\hline No & NAMA PERUSAHAAN & UMUR & PROFITABILITAS & TYPE \\
\hline 1 & PT BISI INTERNASIONAL Tbk & 26 & 0.05 & 2 \\
\hline 2 & PT BERLIAN LAJU TANKER Tbk & 28 & -0.1 & 2 \\
\hline 3 & PT BANK MANDIRI (Persero) Tbk & 11 & 0.02 & 1 \\
\hline 4 & PT HOLCIM INDONESIA Tbk & 38 & 0.12 & 2 \\
\hline 5 & PT LIPPO KARAWACI TbK & 19 & 0.03 & 1 \\
\hline 6 & PT INDOSAT TbK & 42 & 0.03 & 2 \\
\hline 7 & PT MITRA INTERNASIONAL RESOURCES TbK & 30 & -0.3 & 1 \\
\hline 8 & PT PANIN BANK TbK & 38 & 0.01 & 1 \\
\hline 9 & PT JASA MARGA (Persero) Tbk & 31 & 0.06 & 1 \\
\hline 10 & PT SAMPOERNA AGRO Tbk & 16 & 0.13 & 2 \\
\hline 11 & PT ADARO ENERGY Tbk & 17 & 0.1 & 2 \\
\hline 12 & PT BANK CENTRAL ASIA Tbk & 52 & 0.03 & 1 \\
\hline 13 & PT BANK NEGARA INDONESIA (Persero) Tbk & 63 & 0.02 & 1 \\
\hline 14 & PT BANK RAKYAT INDONESIA (Persero) Tbk & 114 & 0.04 & 1 \\
\hline 15 & PT SEMEN GERSIK (Persero) Tbk & 52 & 0.26 & 2 \\
\hline 16 & PT TIMAH (Persero) Tbk & 33 & 0.06 & 2 \\
\hline 17 & PT BAKRIE SUMATERA PLANTATIONS TbK & 98 & 0.05 & 2 \\
\hline 18 & PT UNITED TRACTORS Tbk & 37 & 0.16 & 2 \\
\hline 19 & PT ANEKA TAMBANG (Persero) Tbk & 41 & 0.06 & 2 \\
\hline 20 & PT ASTRA INTERNASIONAL Tbk & 52 & 0.11 & 2 \\
\hline 21 & PT BARITO PASIFIK Tbk & 30 & 0.07 & 1 \\
\hline 22 & PT ELNUSA Tbk & 40 & 0.05 & 2 \\
\hline 23 & PT INTERNASIONAL NIKEL INDONESIA TbK & 41 & 0.08 & 2 \\
\hline 24 & PT INDOFOOD SUKSES MAKMUR TbK & 19 & 0.13 & 2 \\
\hline 25 & PT ASTRA AGRO LESTARI Tbk & 26 & 0.22 & 2 \\
\hline 26 & PT INDOCEMENT TUNGGAL PERKASA Tbk & 24 & 0.22 & 2 \\
\hline 27 & PT TAMBANG RAYA MEGAH Tbk & 22 & 0.36 & 2 \\
\hline 28 & PT KALBE FARMA Tbk & 43 & 0.14 & 2 \\
\hline 29 & PT MEDCO ENERGY INTERNASIONAL Tbk & 29 & 0.9 & 2 \\
\hline 30 & PT PERUSAHAAN GAS NEGARA (Persero) Tbk & 44 & 0.27 & 2 \\
\hline 31 & PT BUKIT ASAM (Persero) Tbk & 90 & 0.44 & 2 \\
\hline 32 & PT TELKOMUNIKASI INDONESIA Tbk & 153 & 0.23 & 2 \\
\hline 33 & PT DANAMON INDONESIA Tbk & 53 & 0.02 & 1 \\
\hline 34 & PT INDIKA ENERGY Tbk & 9 & 0.02 & 2 \\
\hline 35 & PT PP LONDON SUMATRA Tbk & 103 & 0.21 & 2 \\
\hline 36 & PT UNILEVER INDONESIA Tbk & 76 & 0.2 & 2 \\
\hline
\end{tabular}

Tabel 2 Indeks Nilai Karakteristik Perusahaan 


\section{Pengaruh karakteristik perusahaan} 80

Tabel 3

Hasil Pengujian Statistik Deskriptif

\begin{tabular}{lccc}
\hline & Tk & Age & prof \\
\hline $\mathrm{N} \quad$ Valid & 36 & 36 & 36 \\
\multicolumn{1}{r}{ Missing } & 0 & 0 & 0 \\
Mean &, 66830 & 45.56 &, 1243 \\
Std. Deviation &, 140898 & 31.531 &, 18481 \\
Minimum &, 471 & 9 &,- 29 \\
Maximum &, 941 & 153 &, 90 \\
\hline
\end{tabular}

Berdasarkan tabel 1 diketahui bahwa nilai kinerja social berdasar pengungkapan ISO 26000 (tk) yang tertinggi adalah 0,941 dengan item pengungkapan sebanyak 32 item pengungkapan oleh PT. Bank Negara Indonesia Tbk. dan terendah adalah PT. Astra Internasional Tbk. dengan nilai 0,471 serta 16 item pengungkapan dari total keseluruhan sebesar 34 item. Rata-rata informasi kinerja sosial berdasar ISO 26000 yang diungkapkan perusahaan bernilai 0,668 atau $66,8 \%$ sebesar 23 item pengungkapan dengan standar deviasinya 0,14. Standard deviasi yang kecil ini (kurang dari 30\% dari mean, menunjukkan bahwa variasi data seluruh sampel cukup kecil atau kesenjangan kinerja social berdasar ISO 26000 dari yang terendah dan tertinggi cukup kecil. Sehingga, datanya relative mengumpul disekitar nilai rata-ratanya. Dan dengan hasil tersebut, rata-rata kinerja sosial yang sudah dilakukan oleh perusahaan-perusahaan itu lebih dari 50\%.

Rata-rata umur perusahaan adalah 45,56 tahun, dengan standar deviasi 31,531, berarti terjadi kesenjangan yang cukup tinggi antara perusahaan tertua dan termuda. Dimana perusahaan tertua adalah PT. Telekomunikasi Indonesia Tbk. yang berusia 125 tahun, sedang yang paling muda adalah PT. Indika Energy Tbk. dengan umur 9 tahun.

Rata-rata rasio profitabilitas perusahaan sampel adalah $12,43 \%$ di atas ratarata perusahaan besar dengan prosentase $9 \%$. Profitabilitas tertinggi dimiliki oleh PT. Medco Energi Internasional Tbk sebesar 90\%, sedang rasio paling rendah adalah PT. Mitra Internasional Resources Tbk dengan rasio - $29 \%$ atau di bulatkan menjadi - $30 \%$. Standar deviasi sebesar 18,48 \% menunjukkan bahwa terjadi kesenjangan antara rasio profitabilitas tertinggi dan terendah.

Untuk tipe perusahaan, disini digolongkan 2 jenis perusahaan seperti yang sudah di jelaskan. Dari total jumlah sampel yaitu 36 perusahaan, 26 perusahaan sebesar $72,2 \%$ termasuk high profile. Dan untuk 10 perusahaan sebesar 27,8\% termasuk kategori low profile.

\section{Hasil Uji Asumsi Klasik}

\section{Uji Normalitas}

Untuk mengetahui data terdistribusi normal atau tidak, maka dihitung rasio skewness dengan standart error of skewness untuk poin kinerja social berdasar ISO 26000 yaitu tk $(0,533 / 0,393=1,356)$ karena nilainya berada di antara -2 sampai 2, maka data berdistribusi normal. Perhitungan untuk poin umur yaitu age $(1,716 / 0,393=4,366)$ karena nilainya berada di atas -2 sampai 2 , maka data tidak berdistribusi normal. Sama halnya dengan poin profitabilitas yaitu prof $(2,024 / 0,393=5,15)$ karena nilainya berada di atas -2 sampai 2 , maka data tidak berdistribusi normal.

Dan untuk mengetahui kurtosisnya adalah dengan mengitung rasio kurtosis dengan standart error kurtosis pada poin umur yaitu age $(3,085 / 0,768=4,01)$ dan poin profitabilitas yaitu prof $(8,677 / 0,768=11,298)$ karena kedua poin mempunyai nilai berada diatas -2 sampai 2 jadi data tidak berdistribusi normal. Begitu juga untuk kinerja sosial berdasar ISO 26000 Dihitung juga dengan (-1,024/ $0,768=-1,333)$ karena nilainya di antara -2 sampai 2 maka data terdistribusi normal. 
Dikarenakan dua data, yaitu age dan prof yang sudah diolah tidak berdistribusi normal, maka data di normalkan atau ditransfrom dahulu dengan dengan menggunakan LN (Logaritma Numeric)

\section{Uji Multikolinearitas}

Uji multikolinearitas data dapat dilakukan dengan matriks korelasi dengan melihat besarnya nilai VIF (variance inflation factor) dan nilai tolerance. Suatu model regresi yang bebas dari multikolinearitas memiliki angka VIF di sekitar 1 dan angka tolerance mendekati 1 . Hasil uji multikolinearitas

Bahwa nilai VIF dari masing-masing variabel yaitu, tipe perusahaan (type), transform umur (tr_age), transfrom profitabilitas (tr_prof) kurang dari 10 dan nilai tolerance lebih dari 0,10 . Maka, dapat disimpulkan bahwa tidak terjadi multikolinearitas antar variabel independent dalam model regresi.

\section{Uji Heteroskedastisitas}

Model regresi yang baik adalah yang homoskedastisitas, dimana salah satu cara untuk melihat ada atau tidaknya heteroskedastisitas ini adalah dengan melihat grafik plot antara variabel dependen (ZPRED) dengan residualnya (SRESID). Penelitian ini tidak mengandung heterokedastisitas karena dilihat dari grafik scatter plot, titik-titik menyebar secara acak serta tersebar baik di atas maupun di bawah angka nol (0) pada sumbu Y.

\section{Pengujian Hipotesis}

\section{Hasil Uji Regresi Berganda}

Hasil dari pengujian regresi berganda dengan tiga variabel independen adalah sebagai berikut:

\begin{tabular}{cc|ccc}
\hline & \multicolumn{2}{c}{ Unstandardized Coefficients } & T & Sig. \\
\cline { 2 - 3 } Model & B & Std. Error & 1.697 & .100 \\
(Constant) & .382 & .225 & -.645 & .524 \\
Type & -.041 & .064 & .232 & .818 \\
tr_prof & .006 & .028 & 3.041 & .005 \\
tr_age & .105 & .035 & \\
\hline
\end{tabular}

a. Dependent Variable: tk

\begin{tabular}{llccccc}
\hline & Model & Sum of Squares & Df & Mean Square & $\mathrm{F}$ & Sig. \\
\hline 1 & Regression & .167 & 3 & .056 & 3.489 & $.028^{\text {a }}$ \\
Residual & .478 & 30 & .016 & & \\
Total & .644 & 33 & & & \\
\hline
\end{tabular}

Hasil Uji Regresi dan Uji t(Parsial)

Dari hasil output maka dapat disimpulkan pengujian hipotesis penelitian ini sebagai berikut:

Dapat ditarik kesimpulan bahwa, signifikansi $<0,05(0,028<0,05)$, maka Ho ditolak yang berarti bahwa umur perusahaan, tingkat profitabilitas dan tipe perusahaan secara bersama-sama berpengaruh terhadap kinerja sosial berdasar ISO 26000.

Hipotesis satu tentang umur perusahaan bepengaruh terhadap kinerja sosial perusahaan berdasar ISO 26000 dapat dikatakan berpengaruh signifikan. Hal ini dimungkingkan karena manajemen perusahaan dari tahun ke tahun belajar dan memperbaiki kinerja sosialnya untuk lebih menyempurnakan citra perusahaan terhadap masyarakat khususnya pada investor ataupun kreditur. Hal itu didukung 


\section{Pengaruh karakteristik perusahaan}

oleh penelitian yang dilakukan oleh Choi (1998) dan memberi kesimpulan bahwa semakin tua umur perusahaan, maka nilai reputasinya dan aktivitas sosialnya pun akan semakin tinggi pula. Penelitian ini juga mendukung penelitian yang dilakukan oleh Sembiring (2005) dan Suripto (1999) yang berhasil menemukan korelasi antara umur perusahaan terhadap pengungkapan tanggung jawab sosial.

Sedang hipotesis dua tentang faktor profitabilitasm maka dapat dikatakan bahwa tingkat profitabilitas tidak berpengaruh terhadap kinerja sosial berdasar ISO 26000. Faktor yang memungkinkan adalah ketika perusahaan memiliki tingkat laba yang tinggi, perusahaan (manajemen) menganggap tidak perlu melaporkan hal-hal yang dapat mengganggu informasi tentang sukses keuangan tersebut. Sebaliknya ketika tingkat profitabilitas rendah perusahaan akan berharap pengguna laporan akan membaca kinerja sosial perusahaan. Berdasar kesimpulan di atas, maka hasil dari penelitian ini tidak mendukung beberapa penelitian yang sebelumnya. Seperti yang dinyatakan oleh Donovan dan Gibson (1999), dari sisi teori legitimasi, profitabilitas berpengaruh negatif terhadap pengungkapan tanggung jawab sosial perusahaan. Hal ini didukung dengan argumentasi bahwa ketika perusahaan memiliki tingkat laba yang tinggi, perusahaan (manajemen) menganggap tidak perlu melaporkan hal-hal yang dapat menganggu informasi tentang sukses keuangan perusahaan. Sebaliknya, pada saat tingkat profitabilitas rendah, manajemen berharap para pengguna laporan akan menilai kinerja perusahaan dalam kondisi bagus. Hal ini menurut Gray, et al, (1995) dalam Sembiring (2005) disebabkan karena pengungkapan tanggung jawab sosial perusahaan tidak berhubungan dengan profitabilitas dalam periode yang sama, tetapi mungkin berhubungan dengan laba periode yang lalu (lagged profit).

Namun, penelitian ini mendukung beberapa penelitian terdahulu, menurut Kokobu et.al (2001) dalam Sembiring (2005) terdapat hubungan positif antara kinerja ekonomi suatu perusahaan dengan pengungkapan tanggung jawab sosial. Hal ini dikaitkan dengan teori agensi bahwa perolehan laba yang semakin besar akan membuat perusahaan mengungkapkan informasi sosial yang lebih luas. Sementara itu, penelitian yang dilakukan Bowman dan Haire (1976) dan Preston (1978) dalam Hackston dan Milne (1996) juga menunjukkan bahwa semakin tinggi tingkat profitabilitas perusahaan maka semakin besar pengungkapan informasi sosial. Maka dugaan awal $\left(\mathrm{H}_{2}\right)$ tidak terbukti dalam penelitian ini.

Demikian juga hipotesis ketiga tentang tipe Perusahaan,dapat dikatakan bahwa tipe perusahan tidak berpengaruh signifikan terhadap kinerja sosial berdasar ISO 26000. Artinya pemakai laporan keuangan tidak pernah mempertimbangkan tipe perusahaan itu, apakah perusahaan tersebut berkaitan langsung dengan lingkungan atau tidak, bukanlah faktor yang dipertimbangkan untuk pengambilan keputusan. Hasil ini tidak mendukung penelitian yang dilakukan oleh Hackston dan Milne (1996), Machmud dan Djakman (2008), Utomo (2000), Anggraini (2006), Sembiring (2005) dan Sumedi (2010) yang menyatakan bahwa variabel tipe industri berpengaruh signifikan terhadap pengungkapan CSR. Hubungan antara tipe industri dan pengungkapan CSR mengandung arti bahwa industri high profile akan cenderung melakukan pengungkapan CSR lebih banyak.

\section{Simpulan dan Saran}

Berdasarkan hasil penelitian tentang pengaruh karakteristik perusahaan dan kinerja sosial perussahaan di Indonesia dapat dikatakan bahwa rata-rata kesadaran perusahaan dalam melakukan pengungkapan kinerja sosial / Corporate Sosial Performance yang berdasarkan ISO 26000, sudah cukup tinggi. Hal itu ditunjukkan pada nilai rata-rata kinerja sosial sudah melebihi standar yang ada. Dibalik itu semua, masih belum ada satupun perusahaan yang melakukan semua kinerja sosial berdasar kategori dalam ISO 26000. Didalam standar ini, kategori tata kelola organisasi, praktik ketenaga kerjaan dan pembangunan sosial 
ekonomi masyarakat mendapat perhatian yang besar untuk diungkapkan oleh perusahan.

Dalam penelitian ini karakteristik perusahaan diukur dengan tiga elemen

yaitu: umur, tingkat profitabilitas dan tipe perusahaan. Rata-rata umur perusahaan sudah cukup matang/tinggi. Begitu juga dengan rata-rata tingkat profitabilitasnya, juga berada di atas standard rata-rata perusahaan besar. Sedangkan ratarata tipe perusahaan didominasi oleh perusahaan high profile.

Hasil pengujian hipotesis menunjukkan bahwa semua variabel independen (umur perusahaan, tingkat profitabilitas dan tipe perusahaan) secara simultan berpengaruh signifikan terhadap kinerja sosial berdasar ISO 26000. Namun hasil uji t menunjukkan secara parsial, bahwa hanya umur perusahaan yang berpengaruh terhadap kinerja social perusahaan.

\section{Saran}

Penelitian lain dapat menganalisis dengan menggunakan dua atau lebih periode penelitian sebagai pembanding. Serta menggunakan data variabel penelitian dan indikator pengukuran yang berbeda. Dan juga membandingkan pengungkapan antara annual report dan official website.

\section{Daftar Pustaka}

Anggraini, Reni Retno. 2006. "Pengungkapan Informasi Sosial dan Faktor-Faktor yang Mempengaruhi Pengungkapan Informasi Sosial dalam Laporan Keuangan Tahunan (Studi Empiris pada Perusahaan-Perusahaan yang terdaftar di Bursa Efek Jakarta)".Simposium Nasional Akuntansi IX, Padang, 23-26 Agustus.

Arikunto, Suharsimi. 1998. Prosedur Penelitian Suatu Pendekatan Praktek. Jakarta.Rineka Cipta.

Darwin, Ali. 2004. "Penerapan Sustainability Reporting di Indonesia".Konvensi Nasional Akuntansi V. Program Profesi Lanjutan. Yogyakarta.

Deegan, C. 2000. Financial Accounting Theory. Rosevill, NSW: McGraw-Hill.

Ghozali, L. 2007. Aplikasi Analisis Multivariate dengan Program SPSS. Badan Peneliti Universitas Diponegoro.

Hackston, David dan Markus J. Milne. 1996. "Some Determinants of Social and Environmental Disclosures in New Zealand Companies". Accounting, Auditing \& Accountability Journal. Vol. 9 No. 1.

Jalal. 2008. "Sejarah dan Masa Depan CSR Menurut Min-Doung Paul Lee". http:/ /Www.csrindonesia.com/data/articles/20080522135849-a.pdf (diakses 28 Desember 2010).

Kasali, Rhenald. 2005. Manajemen Public Relations. Jakarta. Ghalia Indonesia.

Leung Luk, C. Yau. Oliver H.M. Tse. Alan CB. Sin. Leo. Chow. Raymond. 2005 "Stakeholders Orientation and Business Performance: The Case of Service Companies in China”. Journal of International Marketing. 1069031X, Vol.13.

Marwata. 2001. "Hubungan Antara Karakteristik Perusahaan dan Kualitas Ungkapan Sukarela Dalam Laporan Tahunan Perusahaan Publik Di Indonesia”. Simposium Nasional Akuntansi IV. Bandung. pp 155-173.

Maulana, Makki. 2008. Corporate Social Responsibilities: Legitimasi, Kepatuhan terhadap Peraturan, ataukah Award? (Studi Kasus pada PT. Phapros, Tbk).

Sembiring, Edi Rismanda. 2005. "Karakteristik Perusahaan dan Pengungkapan Tanggung Jawab Sosial: Studi Empiris pada Perusahaan yang Tercatat di Bursa Efek Jakarta”. Makalah Disampaikan dalam Simposium Nasional Akuntansi VIII. Solo, 15 - 16 September. 


\section{Pengaruh karakteristik perusahaan}

Solihin, Ismail. 2008. Corporate Social Responsibility from Charity to Sustainibility. Jakarta: Salemba Empat

Suripto, Bambang.1999. "Pengaruh Karakteristik Perusahaan Terhadap Luas Pengungkapan Sukarela Dalam Laporan Tahunan". http://www.mediaglobalekonomi.com/548654df/sentra_ty/html (diakses 20 Oktober 2009).

Susanto. Djoko. 1992. "An Empirical of the Extent of Corporate Disclosure in Annual Report Companies Listed on Jakarta Stock Exchange”. Dissertatation. University of Arkansas, USA.

Utomo, Muslim, 2000. "Praktek Pengungkapan Sosial pada Laporan Tahunan Perusahaan di Indonesia (Studi Perbandingan antara PerusahaanPerusahaan High-Profile dan Low-Profile)". Simposium Nasional Akuntansi III.

Windsor, Duane. 2010. Business And Society Jurnal. Vol 46 Number 3. Downloaded from bas.sagepub.com at Airlangga University on October 17, 2010

www.csrindonesia.com 